\title{
DEFINITION AS A GENRE IN THREE LEGAL SYSTEMS: A COMPARATIVE ANALYSIS
}

\section{VIRGINIA VECCHIATO, PhD student}

\author{
Università degli Studi di Modena e Reggio Emilia \\ Largo S. Eufemia 19, 41121 Modena, Italy \\ virginia.vikk@gmail.com
}

\section{ORCID: https://orcid.org/0000-0002-0490-0044}

\begin{abstract}
This paper aims at comparing the definition of 'trademark' in three different legal systems - EU law, international law and US common law - in order to identify the discoursal, generic and textual characteristics of definition as a genre. The selected corpus of analysis is made up of three definitions from EU Regulation 2017/1001, WTO Agreement on Trade-Related aspects of Intellectual Property Rights (TRIPS) and US Lanham Act (sec.45) and of several US cases from 1926 to 2019. The theoretical framework within which the analysis is carried out is the seminal work on definition as carried out by Richard Robinson (1954) and Harris and Hutton (2007). The approach is mainly linguistic, though a historical excursus on the concept of definition is provided as a necessary introductory premise. The findings demonstrate that EU legal texts are characterised by a hybrid style (Robertson 2010) which results from the combination of common law and civil law textual features.
\end{abstract}


The analysis of the definitional sections here displayed supports this point and confirms that EU term formation and definition are text-driven (Šarčević 2016). EU legal texts in their English version originate from the dynamic combination of two aspects: one connected to EU legal English - which is not common law English - and one connected to matters of terminology, syntax and general structure which has a French origin.

Key words: definition; legal language; discourse analysis; interpretation; semiotics.

\title{
DEFINICJA JAKO GATUNEK W TRZECH SYSTEMACH PRAWNYCH: ANALIZA PORÓWNAWCZA
}

\begin{abstract}
Abstrakt: W artykule porównuje się definicje pojęcia 'trademark' w trzech systemach prawnych - prawie UE, prawie międzynarodowym i amerykańskim common law - w celu określenia dyskursywnych, gatunkowych i tekstowych cech definicji jako gatunku. Korpus analizowanych tekstów składa się z trzech definicji zawartych w rozporządzeniu UE 2017/1001, Porozumieniu WTO w sprawie handlowych aspektów praw własności intelektualnej (TRIPS) i amerykańskiej ustawie Lanhama (par. 45) oraz w aktach kilku spraw sądowych z USA z lat 1926-2019. Ramy teoretyczne analizy zawarte są w pracach poświęconych zagadnieniu definicji autorstwa Richarda Robinsona (1954) oraz Harrisa i Huttona (2007). Niniejsza praca ma zasadniczo charakter językoznawczy, zawiera jednak także niezbędny tu wprowadzający ekskurs historyczny. Rezultaty badania wskazują, że teksty prawne UE charakteryzuje styl hybrydowy (Robertson 2010), wynikający z połączenia cech prawa common law i prawa kontynentalnego. Świadczy o tym analiza omówionych $\mathrm{w}$ pracy partii definiujących, która zarazem potwierdza, że kształtowanie się terminu unijnego i jego definicja mają charakter tekstowy (text-driven) (Šarčević 2016). Teksty prawne UE w wersji angielskiej powstają z dynamicznego połączenia dwóch aspektów: pierwszy wiąże się z prawnym językiem angielskim UE - który nie jest angielszczyzną common law - a drugi z problematyką terminologii, składni i struktury ogólnej.
\end{abstract}

Słowa kluczowe: definicja; język prawny; analiza dyskursu; interpretacja; semiotyka.

\section{LA DEFINIZIONE COME GENERE IN TRE ORDINAMENTI GIURIDICI: UN'ANALISI CONTRASTIVA}

Abstract: Il presente contributo mette a confronto la definizione di
'trademark' come riconosciuta in tre diversi ordinamenti giuridici - diritto
comunitario, diritto internazionale e common law statunitense - al fine di 
identificare le caratteristiche della definizione come genere testuale. Il corpus di analisi è costituito da tre definizioni tratte dal Regolamento UE 2017/1001, dall'Agreement on Trade-Related aspects of Intellectual Property Rights (TRIPS), dal Lanham Act e da diversi casi dibattuti fra il 1926 e il 2019 nei tribunali statunitensi. Il quadro teorico all'interno del quale si svolge l'analisi è la ricerca sulla definizione svolto da Richard Robinson (1954) e Harris e Hutton (2007). L'approccio è prevalentemente linguistico, anche se un excursus storico sul concetto di definizione è fornito come necessaria premessa introduttiva. I risultati dimostrano che $\mathrm{i}$ testi giuridici dell'UE sono caratterizzati da uno stile ibrido (Robertson 2010) che deriva dalla combinazione delle caratteristiche testuali del diritto comune e del diritto civile. L'analisi delle sezioni di definizione qui analizzate supporta questo punto e conferma che la formazione e la definizione dei termini UE sono textdriven (Šarčević 2016). I testi giuridici comunitari nella loro versione inglese hanno origine dalla combinazione dinamica di due aspetti: uno legato all'inglese giuridico dell'Unione - che non è l'inglese del common law - e uno legato a questioni terminologiche, sintattiche e generiche da ricondurre alla lingua francese.

Key words: definizione; linguaggio legale; analisi del discorso; interpretazione; semiotica.

\section{Introduction}

The original stimulus for this paper was an enlightening paper by Colin Robertson (2012) who carried out a comparative analysis between common law and civil law discoursal, generic and linguistic peculiarities in order to identify their influence on European Legal English. Although many other scholars have investigated the differences and similarities of common law and civil law legal systems (Bhatia 1993, Foley 2002, Pozzo 2016, Šarčević 2016) from different perspectives, Robertson assumes that EU Legal English is neither a dialect nor a variant of standard English but a new genre. As a genre, Robertson (2010, 2011, 2012) and other scholars (Mattila 2013, Cacchiani 2015, Felici 2016) recognize hybridity as one of the main characteristics of EU legal discourse, whose source of creation are treaties - prototypical textual expression of international law - and whose textual outcome are binding documents, drafted in 'the' English 
- which is not the common law language - and characterised by terminology, syntax and general structure of French origin.

As definitions are an important section in EU legal documents - in particular in regulations and directives - in international agreements and in common law statutes, this paper aims at identifying the linguistic (textual and discoursal) peculiarities and the cognitive structure of these sections in a selected collection which consists of the definition of the term 'trademark' in European, international and common law context of competition law. In order to carry out this analysis, the seminal work on definition by Richard Robinson (1954) provides the theoretical framework which has been complemented with Harris and Hutton's integrationist approach (2007) applied to legal definition, which makes Robinson's stipulative definition central to the topic of definition.

The discoursal hybridity which characterizes EU legal texts is ascribable to the peculiarity of the European legal order, where the coexistence of national, international and supranational law reflects the society which these legal orders regulate, and addresses "a need for consistency, coherence, predictability and certainty [which] leads to efforts to harmonize the rules across the range of fields and make them compatible with each other" (Robertson 2016: 42).

The concept behind and within 'trademark' seems to be a telling example of the hybridity - discoursal, terminological, cognitive but also jurisprudential - which characterizes EU textography (Swales 1998). As an example, it sheds light on the 'crucible', namely on the space in which EU "legislative language is tested and refined" (Foley 2002: 362) and proves the European legal order to be "a synthesis of interaction of the relevant rules of international law and the laws and jurisprudence of the European Union" (Muravyov 2003 in Smyrnova 2013: 126).

Thus, the ultimate aim of this paper is to demonstrate whether the discoursal hybridity of EU legal language - which results from the process of legal harmonization - is recognisable in the definitional sections of EU legal acts and whether these definitional sections have the features of a text type "developed as a pattern of message for certain communicative situation [...] evolved from conventionalised situations" (Sager 1997). As legislative statements have a conventionalized communicative purpose (Bhatia 1993: 117), this analysis questions whether definitional sections (or definitions) in legal 
documents have the characteristics of a subgenre since they serve one main communicative purpose.

The concept selected for the analysis belongs to the branch of competition law, because the three legal systems of reference have a consolidated tradition in this field and in particular, according to the EU legislative praxis as ratified in art. 103 TFEU "The Union shall have exclusive competence in the [...] establishing of the competition rules necessary for the functioning of the internal market".

\section{Method and material}

The analysis used three definitions of the term 'trade(-)mark' as shown in EU Regulation 2017/1001 - as an example of supranational law, in WTO Agreement on Trade-Related aspects of Intellectual Property Rights - as an example of international law, and in US Lanham Act and certain of US cases from 1926 to 2019 - as an example of national (and common) law. The method adopted to describe the textual and generic characteristics of the definitions was genre analysis (Bhatia 1993, 2004; Swales 1998) and in particular the structural interpretation of the textgenre as presented in Bhatia (1993: 29-34) in terms of interactive cognitive structure. For each definition, the cognitive structure was made clear through a graphic representation, which emphasized two main aspects: 1) each step (Rasmussen and Engberg 1999) or move (Swales 1990; Bhatia 1993) recognizable in the definitions at issue (estensive, intensive, ostensive, denotative, implicative, and rule-giving to name but a few) fulfilled a particular communicative function; 2) the combination of the identified steps created recurrent patterns, which were useful variables to investigate and identify genres.

\section{Theoretical framework}

Even though there may be a common agreement on the usefulness of 'definition' as a procedure to understand the essential nature of a thing or a word used by some actual individuals which, otherwise, would not be able to give sense to the material and immaterial phenomena which 
characterise their everyday life, it is difficult to provide an unambiguous and universally accepted definition of 'definition' since it is a multifaced concept which has been investigated for centuries - starting from Plato in the IV century B.C. - by philosophers, logicians, mathematicians and linguists from different epistemological perspectives. The simple and common-sense definition (also known as lexical definition) provided in the opening sentence of this paragraph is just one out of eighteen species of definition which Robinson (1954: 7) identifies and which are ascribable to three main approaches to definitions: realist, nominalist and conceptualist. In addition, Harris and Hutton (2007: 18-19) propose their "integrationist approach [which] recognizes definitions as being stipulative" since "they provide practical guidelines for the conduct of communicational activities". After presenting these approaches theoretically but briefly - due to the limited space and the purpose of this paper - in the next section, they will be applied to legal definitions and in particular to a collection of definitions from legal written documents which belong to three legal systems: EU law, international law and US common law (and case law).

\subsection{Definition defined}

By the phrase 'species of definition' mentioned in the paragraph above, Robinson refers to both purposes and methods of a definition. Basically, a definition is a mental activity, which provides the ground where logic and psychology touch and which may be described as a "secondary symbolic activity" (Robinson 1954: 13), namely a subsequent process that reflects on the use of symbols or linguistic signs. As far as communicative purpose is concerned, a preliminary distinction between real definition (or definition of things, or res) and nominal definition (be it a word-word definition or a word-thing definition or definition of words, nomina) is necessary. The former kind of definition - real definition or thing-thing definition - dates back to Socrates and Plato, who are "the inventors of the notion of definition" (Robinson 1954: 149) and to Aristotle. In many writings, Plato's model of discussion starts with a question having the form 'What is $\mathrm{x}$ ?', namely with a request for a definition. In particular, in Theaetetus, the question to answer through the dialogue is 'What is logos?' where logos is a thing 


\section{Comparative Legilinguistics 44/2020}

and not a word. The answer presupposes that one already knows the use of the word, which, as something that is a weaving together of the names of the elements of a thing, must be suitably explanatory (Fine 1979). If with Plato, logos refers to either 'sentence' or 'statement' or 'explanation' or 'account' producing knowledge - namely to definition - Aristotle in Topics defines definition as "the statement that gives the essence" of a thing, not of a word. The reocentric view of meaning (Harris and Hutton 2007: 24) - which links Plato, Aristotle, Cicero (in Rhetorica ad Herennium, Book IV, "Definition in brief and clear-cut fashion grasps the characteristic qualities of a thing, [...] and is accounted useful for [...] it sets forth the full meaning and character of a thing so lucidly and briefly that to express it in more words seems superfluous, and to express it in fewer is considered impossible") over the centuries through Spinoza to J.S. Mill - depends on the existence of the ' $x$ ' mentioned in the question. Thus real definition appears as an Analysis, with a capital letter, since several processes - 'abstraction', 'relation', 'synthesis' and 'substitution' - from which the vague formula 'What is $\mathrm{x}$ ?' flourishes from are implied (Robinson 1954: 178ff). The analytic enumeration of the simple ideas (Locke 1706) which combine in the meaning of the term to be defined, hints at the existence of complex ideas made up of simple ideas or natural kind terms which "play an important role of pointing to common 'essential features' or 'mechanisms' beyond and below the obvious distinguishing characteristics" (Putnam 1970: 188) and which, for this reason, are not definable.

In contrast with this last assertion on indefinability, Robinson states that "nothing is lexically indefinable" (1954: 41) and that this consolidated misunderstanding is due - among different reasons connected to the emotional force and the indicative power of a word to the fact that 'indefinable' does not mean 'non-admitting a definition' but rather 'non-requiring a definition'. This refers to the abovementioned nominal definition, which exists as word-word definition or as word-thing definition.

Word-word definition has the form of an interlingual translation, as it is "an interpretation of verbal signs by means of other signs of some other language" (Jakobson 1959: 233) and it correlates a word to another word having the same meaning; word-thing definition correlates a word to a thing. The relationship established between a word and a thing serves two distinct purposes and originates the lexical (or historical) definition and the stipulative (or legislative) definition. 
Lexical definition, which provides a customary or dictionary meaning of the word at issue, is a form of history (Robinson 1954: 35) and reports "the meaning that a word has in a language" (Hurley 1988: 82). It basically involves three agents: the definer (or the lexicographer), the hearer (or reader) and the user (or the individual whose usage of the word gives the word itself the meaning it has). It provides four dimensions of the word in question, namely the contextual, the syntactical, the expressive and the indicative one, since its ultimate goal is to say how words are used. As descriptive linguists, lexicographers empirically analyse and describe a language with a traditional emphasis on individual items of vocabulary and fulfil a function of mediation between the community of linguists and the community at large (Kirkness 2004). With Harris and Hutton (2007: 78), "lexicographical definition is deliberately constructed and allocated by the lexicographer on the basis of materials selected for study, and its allocation depends on the viewpoint the lexicographer has chosen to adopt". As a matter of fact, dictionaries are "books or banks about words" (Kirkness 2004: 59), while encyclopaedias are " books or banks about facts" (Kirkness 2004: 59): "the Cyclopaedia describes things, the Dictionary explains words, and deals with the description of things only so far as is necessary in order to fix the exact signification and use of words" (Murray 1884 in Harris and Hutton 2007: 81, italics in the original). Yet, although the distinction between dictionaries and encyclopaedias is pretty obvious, "a hard and fast distinction between lexical and encyclopaedic information is not possible [...] since humans use language to communicate about facts, things or people" (Kirkness 2004: 59) through linguistic signs.

Stipulative definition, which provides one's own meaning for a word and reports or establishes the meaning of a (linguistic) sign, is "an announcement of what is going to be meant by it in a work, or a request to the reader to take it in that sense" (Robinson 1954: 59). In the act of assigning an object to a name, the lexicographer is not recording an already existing assignment, but is showing how words should be used (Robinson 1954: 59). From the legal Latin word stipulatio, which means "a solemn promise, a contract, or an obligation", stipulative definition makes the lexicographer a legislator (Robinson 1954: 54) or an arbiter (Robinson 1954: 56) who attempts to replace the varieties of actual usage by a single unambiguous usage. As a request or a binding commitment, stipulative definition is a proposal rather than a proposition and looks to the future - not to the past - in a sort of "turning 
our backs to reality" (Robinson 1954: 69). In Harris and Hutton (2007: 71), "stipulative definitions function as performatives - in something like the Austinian sense of performative" - thus are subject to the kinds of Austinian felicity conditions which performatives in general are subject to. In particular, stipulative definitions - like performatives - do not 'describe' or 'report' or constate anything at all, are not 'true or false' (Austin 1962: 5) and in their lack of truth value, they display their arbitrariness (Robinson 1954: 67) and at the same time their function as a cure for ambiguity. Arbitrariness and ambiguity, but also peculiarity and distinctiveness, characterize legal language when it comes to questions of definition (Goodrich 1987: 54). Since performatives are assertion that do not describe or expose a certain state of affairs, but allows the speaker to perform a real action, what is said to be done is accomplished and consequently a real fact is immediately produced. Performative acts, which according to Austin started from a basic premiss about language as social action, are always situated. If every utterance is a performance, the utterer is actually doing something, which is taken to be the "equivalent of intending something" (Goodrich 1987: 74). When the speech act is legal, to do or to intend something may be interpreted in two ways: on the one hand, it may mean that normative or directive statements are intended to affect behaviour, since law prescribes behaviour by means of a generic set of conventional meanings. On the other hand, it may refer to the utterer's intentions (the intentions within a rule or a statute) which have to be recognised by the listener who intends the intentions behind the utterer's words (Hart 1952) and for this reason this second sense pertains to the realm of subjectivity. This look at law in terms of being a concept connected to social life implies that legal norms are acts of will "intentionally directed to the behaviour of another" (Kelsen 1981: 180) and as legal speech acts, they have a formal rather than material attribute. Legal speech acts are different from everyday speech acts in that they "invoke the rules and conventions of the law and carries with it a certain legal force" (Fiorito 2006: 103), they create obligations, permissions, and prohibitions. As an example, it is possible to mention international treaties, conventions and protocols which are all different names to refer to what they are in their essence, namely contracts (Robertson 2016: 60) which compel the parties to perform the acts as recorded in their agreement. 


\subsection{Legal definition defined}

Law only exists in human language (Braekhus 1956 in Mattila 2013, Goźdź-Roszkowski 2011, Engberg 2016) though legal meaning may be different from linguistic meaning (Robertson 2016: 141). Methods of interpretation of legal texts may vary according to the generic feature of the document (Jopek-Bosiacka 2011), thus specific definition is "the chief means by which the precise meaning of a lexical unit is determined and legal certainty is guaranteed" (Alcáraz and Hughes 2014: 30). As Down (in Alcáraz and Hughes 2014) pointed out, interpreting a legal text is construing it ideologically; constructing a legal text is creating it linguistically. Once the legal text has been created, namely constructed, it has to be construed or interpreted by judges or other legal professionals. Allowing that the purpose of interpretation is to construe the law, the legal text is an element in this exegetical process which may take place according to a literal or a liberal approach (Walker 2001 in Robertson 2016: 65): "the need for the courts to try to appreciate the overriding intention of the legislation, the general policy behind the Act and the need to further remedies and not take refuge in pettifogging verbal objections". Alcáraz and Hughes further elaborate on the liberal approach and identify other rules of judicial interpretation: the holistic rule (legal documents are to be interpreted as a whole), the golden rule (ordinary words are to be intended as ordinary words, technical terms as technical terms), the mischief rule (in amending legal texts ambiguous terms are to be construed to facilitate the amending purpose), the ejusdem generis rule (in the presence of a list of hyponyms followed by general words, general words are to be interpreted as referring to other specific items belonging to the same class as the hyponyms), and the rule expression unius est exclusion alterius (in the presence of a list of specific items and in the absence of generic words, the list is to be considered explicitly complete). Not only is the literal approach just one out of several approaches to interpret legal texts, but judicial approaches to interpretation are influenced by the context within the disputes take place and by the legal order of reference. Nonetheless it is possible to identify a 'canon of interpretation', a rule for those involved in the exegetical process, which tends to favour a common sense result rather than a strictly legal or logical outcome, called the rule of leniency, which holds that "any lexical vagueness or syntactic ambiguity is to be 
interpreted against the drafter in both civil and criminal law" (Alcáraz and Hughes 2014: 30).

From a semiotic point of view, the words with which legal documents are drafted are mere signs, "indirect expressions of a reality" (Tiefenbrun 1986: 97), and may be explicit - providing a monoreferential correspondence between word and reality -, deceptive explicit or implicit - when the correspondence between word and reality is not limited to one immediately identifiable meaning. Therefore, both meaning and misunderstanding (linguistic and legal) are located in an intricate relation of signifier/signified/referent (Tiefenbrun 1986: 103) and in this semiotic process of Piercean mediation or thirdness - which characterises the indirect nature of the law - "legal language in written form takes place" (Robertson 2016: 135). These principles also inform Wille's tripartite 'method' (1944) which recognise three stages in the construction of satisfactory legal definitions: as with (legal) definitions the difficulties arise when it is hard to identify the superordinate or the genus of the term to be defined (the 'impossibility thesis' by Benthan 1960 in Hacker 1969: 343), three stages - formation, legal effect or consequence and extinction, namely birth, life and death - may serve the purpose of constructing legal definitions of primary legal ideas. In law, the process of mediation carried out by drafters and judges is a process of interpretation which is not grounded in rules whose meaning is clear and fully determinate in a positivist and Saussurean fashion (Tiefenbrun 1986; Jopek-Bosiacka 2011), but in more realistic and Piercean terms it is a subjective and relatively free mental activity. To Pierce, law is a provisional and openended system (Kevelson 1992), which, tackling the contradiction and paradox inherent in language and in human relations, is prescriptive rather than descriptive, incomplete and reinterpretable. From this perspective, the presence of definition in legal documents and contexts is reasonably justified and fulfils a crucial communicative and operational function, "as shorthand expressions [which] permit the saving of time and energy" (Cairns 1936: 1102).

In addition, "although the legislature cannot change the ordinary meaning of [a word], it does have the power to define the term for the purposes of its legislation" (Tiersma 2000: 116-117) as they are "rules of law" (Cairns 1936: 1103) which however, due to the impossibility to "devise a rule covering all such possible cases in advance", cannot be considered statements of facts in their attempt to be all-inclusive, accessible and transparent (Bhatia 1993, 2010). Words 
are correlated with the fact not solely by the rules of standard English, but also by the rules of law.

In his method of elucidation, Hart (1954) states that the general characteristics of legal language are, first of all, a typical context where legal words are at work. There, by analysing statements of 'rights' and 'duties' - and other legal words - as predictions, namely as texts having a peculiar cognitive property (like instructions, according to Werlich's text typologies (1976), without options and whose communicative function is not to predict the future but to refer to the present without describing it), Hart has no doubt that legal words neither stand for nor describe nor state the existence of anything, but that "when someone has a legal right a corresponding prediction will normally be justified" (Hart 1954: 27).

A second characteristic of legal language is the existence of a legal system made of rules, a third characteristic is that "the same assertion varies its communicative effect according to the function of the speaker who utters it" (Hart 1954: 29) and the fourth and last characteristic is that in any system, rules may attach identical consequences to any one of a set of very different facts (Hart 1954: 30). Hart's truth-conditional definition rejects any sort of analytic definition (Hacker 1969) and suggests a peculiar use of legal concepts rather than peculiar meanings, since "the common use of the words is known but not understood" (Hart 1954: 37). Strictly connected to the above mentioned contextual aspect, in legislative provisions there is a further 'unique contextual factor': the drafting community's first concern is to give in the legal document an honest expression to the intentions of the legislative institution they serve (Bhatia 2010: 46), but, even though the document is meant for ordinary citizens, "the real readers are lawyers and judges, who are responsible for interpreting those provisions for ordinary citizens" (Bhatia 1993: 103).

As it is clear now that the purpose of legal language and in particular of legal definitions is better fulfilled by stipulation rather than by analysis, a third complementary perspective on legal definition is offered by the integrational approach (Harris and Hutton 2007), which makes semantic indeterminacy the background against which participants "construct, impose, contest and debate meaning and seek to impose or deny order, coherence and narrative" (Harris and Hutton 2007: 194). Integrationist indeterminacy is radical and context-oriented as "the sign does not have its own meaning: it is made to mean whatever 
the circumstances require [...] and is subject to recontextualization" (Harris and Hutton 2007: 201-202).

The principles and conventions applied to formulate legal definitions mainly depend on five factors as indicated by JopekBosiacka (2011: 9): 1) type of legal genre; 2) position in the instrument; 3) type of legal definition; 4) legal system; 5) branch of law. For the purposes of this paper, as established in the introduction, the branch of law taken into account is competition law and the contextual legal systems are EU law, international law and, US common law (and case law). As far as concerns the other factors, they are variable or do not provide any operative premise to the analysis since the paper aims at investigating how different definitions of the same legal concept are influenced by different generic, textual and legal contexts.

\subsection{1. 'Trade (-) mark' defined}

The word 'trademark' is highly evocative and once mentioned, generally pictures of famous brands and logos appear in the mind of the general public. People in general agree that trademarks can be valuable for companies, though they would not be equally aware of the fact that trademarks are the most valuable assets in a majority of modern global companies. Trademark value is increasing rapidly in modern society, where more and more of world business is intangible, and consists of trademarks, patents and such assets. Although in everyday speech - and in General English dictionaries, too - trademark and brand are used as synonymous concepts, from a legal perspective there are crucial differences. As a matter of fact, the conventional definition of 'trademark' provided by the online Merriam-Webster Dictionary:

1: a device (such as a word) pointing distinctly to the origin or ownership of merchandise to which it is applied and legally reserved to the exclusive use of the owner as maker or seller 2: a distinguishing characteristic or feature firmly associated with a person or thing ${ }^{1}$. $1 \mathrm{https}: / / \mathrm{www}$. merriam-webster.com/dictionary/trademark
25.06.20)

(accessed 
is followed by the section of synonyms, where the only entry is 'brand'. The same happens with the Britannica Encyclopaedia, which considers 'brand name' as an alternative title to 'trademark', whose definition reads

Trademark, any visible sign or device used by a business enterprise to identify its goods and distinguish them from those made or carried by others. Trademarks may be words or groups of words, letters, numerals, devices, names, the shape or other presentation of products or their packages, colour combinations with signs, combinations of colours, and combinations of any of the enumerated signs ${ }^{2}$.

From the legal point of view, 'brand' is a term that refers to a social activity which may help to build a reputation and thus comprises, among other things, marketing activities. Branding may therefore be defined as a social activity. 'Trademark' is a term that refers to a 'social construction', as it is nourished and developed in relation to a company's existing potential customers and stakeholders. Thus, trademarks are also legal constructions defined and explained by trademark law. The value of a brand is called 'brand equity' and it is based on the presumption that a well-known brand will generate more revenue because potential customers will believe that a product with a well-known brand is better than a product that is less famous. Brand equity is an asset as crucial as impossible to quantify and within its core trademarks are located. As the definition of 'trademark' reads - and confirms - in The Advanced Dictionary of Marketing (2008: 265), 'trade-marks':

are protective legal rights covering words, symbols, phrases, names, or other devices or combinations of such devices associated with ownership of a product or service, and trade secrets, which are processes, patterns, formulas, devices, information, and the like that are known only to their owner (or, in the case of a firm, the owner's employees).

In his telling semiotic interpretation of modern trademark, which appear as a 'floating signifier', Beebe (2004: 622) recognises a triadic structure in every trademark, which appears to be "a set of semiotic relations of reference" among a signifier (or a tangible symbol), a signified (or a type of use) and a referent (or a function or a product). This relational

${ }^{2}$ https://www.britannica.com/topic/trademark (accessed 25.06.20) 
nature, which is inspired with Saussurean semiology and informs the trademark as a 'full-blow sign' and not as a mere signifier, often fails to be recognised and would be the cause of judicial error (Beebe 2004: 650). This premise is necessary since the three elements identified by Beebe and their relation make the trademark deserving of 'trademark rights' and this last aspect is inevitably linked to the legal definition of 'trademark'. The legal definitions which make up the corpus of analysis of this research are presented below in Table 1 .

Table 1. Legal definitions of Trade(-)mark analysed in this article.

REGULATION (EU) 2017/1001 OF THE EURO
PARLIAMENT AND OF THE COUNCIL of 14 June 2017
European Union trade mark.
CHAPTER II
THE LAW RELATING TO TRADE MARKS
SECTION 1
Definition of an EU trade mark and obtaining an EU trade mark
Article 4

Signs of which an EU trade mark may consist

An EU trade mark may consist of any signs, in particular words, including personal names, or designs, letters, numerals, colours, the shape of goods or of the packaging of goods, or sounds, provided that such signs are capable of: (a) distinguishing the goods or services of one undertaking from those of other undertakings; and (b) being represented on the Register of European Union trade marks ('the Register'), in a manner which enables the competent authorities and the public to determine the clear and precise subject matter of the protection afforded to its proprietor.

Article 5

Persons who can be proprietors of EU trade marks

Any natural or legal person, including authorities established under public law, may be the proprietor of an EU trade mark.

Article 6

Means whereby an EU trade mark is obtained

An EU trade mark shall be obtained by registration.

Article 7

Absolute grounds for refusal

The following shall not be registered: [...]

Article 8

Relative grounds for refusal

Upon opposition by the proprietor of an earlier trade mark, the trade mark applied for shall not be registered: [...]

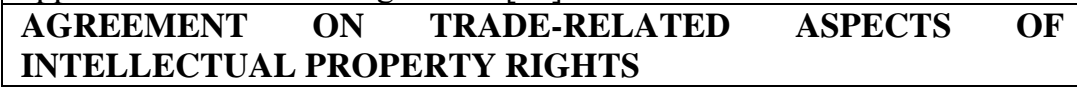




\section{(as amended on 23 January 2017)}

ANNEX 1C

SECTION 2: TRADEMARKS

Article 15

\section{Protectable Subject Matter}

1. Any sign, or any combination of signs, capable of distinguishing the goods or services of one undertaking from those of other undertakings, shall be capable of constituting a trademark. Such signs, in particular words including personal names, letters, numerals, figurative elements and combinations of colours as well as any combination of such signs, shall be eligible for registration as trademarks. Where signs are not inherently capable of distinguishing the relevant goods or services, Members may make registrability depend on distinctiveness acquired through use. Members may require, as a condition of registration, that signs be visually perceptible.

2. Paragraph 1 shall not be understood to prevent a Member from denying registration of a trademark on other grounds, provided that they do not derogate from the provisions of the Paris Convention (1967).

3. Members may make registrability depend on use. However, actual use of a trademark shall not be a condition for filing an application for registration. An application shall not be refused solely on the ground that intended use has not taken place before the expiry of a period of three years from the date of application.

4. The nature of the goods or services to which a trademark is to be applied shall in no case form an obstacle to registration of the trademark.

5. Members shall publish each trademark either before it is registered or promptly after it is registered and shall afford a reasonable opportunity for petitions to cancel the registration. In addition, Members may afford an opportunity for the registration of a trademark to be opposed.

Lanham Act - TITLE X - Construction and definition; intent of the chapter; § 45 (15 U.S.C. § 1127).

The term "trademark" includes any word, name, symbol, or device, or any combination thereof-

(1) used by a person, or

(2) which a person has a bona fide intention to use in commerce and applies

to register on the principal register established by this chapter, to identify and distinguish his or her goods, including a unique product, from those manufactured or sold by others and to indicate the source of the goods, even if that source is unknown.

The three factors which lead the analysis - type of legal genre, position in the instrument, and type of legal definition - cannot exclude a preliminary orthographic remark: in Regulation (EU) 2017/1001, the term at issue is written as a two-word term. Although this is not a radical 
deviation, nonetheless it is choice made by EU drafters if not to avoid misunderstanding or overlapping of a European Union law concept with other terms from other legal systems (Engberg 2016; Šarčević 2016; Anselmi and Seracini 2015), at least to differentiate the spelling of the EU term. In the WTO Agreement and in the US Statute (respectively the second and the third document presented in Table 1) the term is written as a one-word item. Yet, a hyphenated version (trade-mark) was used habitually at the end of the XIX century and at the beginning of the XX century in the US Trade Mark Act of 1881 and in legal judgments such as in Elgin Nat. Watch Co. v. Illinois Watch Case Co. (1901).

As far as concerns the type of legal genre, the EU regulation is an example of secondary legislation, which implements the principles expressed in one or more supranational treaties (primary legislation and typical instrument of international law). Thus, from a treaty voluntarily negotiated by each member state - regulations derive as legally binding documents, immediately after the Member State have ratified them, and become part of the national legal framework of the Member State itself. Regulations - and other legal documents such as directives and decisions - are unique instruments at the EU disposal and characterize the European legal discourse. The second definition is taken from the Agreement on Trade-Related Aspects of Intellectual Property Rights (TRIPS) as amended on 23 January 2017 as an example from international law. International agreements are voluntarily negotiated and ratified documents and their canon is defined in the 1969 Vienna Convention on the Law of Treaties: a treaty is an "agreement concluded between States in written form and governed by international law, whether embodied in a single instrument or in two or more related instruments and whatever its particular designation". The third definition is from Lanham Act, also known as Trademark Act, which is the primary trademark statute in the United States of America. Despite the fact that in the English system of common law judge-made law based on the precedents has always had a prominent role, statutes are the actual form of legislative activity of the British Parliament or the American Congress.

The EU Regulation, the WTO Agreement and the US Act have their own characteristic structure or canon which - as far as concerns EU regulations - is codified in official documents like, for example, the Joint Practical Guide of the European Parliament, the Council and the Commission for persons involved in the drafting of European Union 
legislation (2015). There, it is specified that "[t]he definition must not be contrary to the ordinary meaning of the term (section 14.1) [and] must not contain autonomous normative provisions (section 14.4)". This established canon gives definitions a precise location, and as far as concerns the three examples at issues, in the EU Regulation it has a dedicated section at the beginning of the enacting terms, immediately after the preamble, as in mathematical and physical works where the definitions are necessary premises, "indispensable for a logical or systematic investigation of a subject matter" (Cairns 1936: 1100). Although legal definitions, as nominal definitions, have no truth value, in the context of EU regulations their intermediate position clarify what comes after - as suggested by Plato in the Phaedrus -, but may be no use for what has immediately come before, namely recitals and citations. As far as the WTO document and the US Act are concerned, the definitional sections are respectively in Annex 1C and in Title X (out of XII) thus in final position. This aspect recalls Kant and his point on definitions in philosophy which "are not the conditions of knowledge; they are what we hope to conclude with, not the raw material with which we begin" (White Beck 1956: 188). Although philosophical definitions serve a concluding function as they are the result of elaborations and thus the end product of speculative processes - which justifies their final position - in common law and international law legal definitions have a similar position but a different function. As a matter of fact, the final position of the two definitions at issue seems to provide extra rules or technical data that may be consulted by judges or other legal professionals in the practice of their profession as a reference and not as a premise or as the starting point for their judgement or counsel.

The last aspect to consider is the type of legal definition, namely the methods followed by drafters to construct a given stipulative definition. The basic distinction that serves as a premise is between equative and non-equative definitions (Jopek-Bosiacka 2011: 18). The equative one is the typical legal definition which follows the structure of an equivalence, or a relation between a sign (the definiendum) and something that is not a sign (the definiens) through a defining connective. Within equative definitions it is possible to distinguish intensional (or analytic) definitions and extensional (or synthetic, or synonyms) definitions (Robinson 1954; Jopek-Bosiacka 2011; Alcáraz and Hughes 2014). Notwithstanding "statutory definitions are extensional" (Jopek-Bosiacka 2011: 19), the case of the EU definition 
seems to be quite unusual: in the very first part (art.4) the habitual practice of formulating extensional definition with the phrase shall mean is replaced with the modal may followed by consist followed by a list of examples of what is meant by the word 'signs' and the effect is an extensional chain generated by a series of short 'operational qualifications' (Bhatia 1993: 103) which results in syntactic discontinuities. An example from art. 4 is presented in the scheme below:

Graph 1. Graphic representation of syntactic discontinuity in EU trade mark definition.

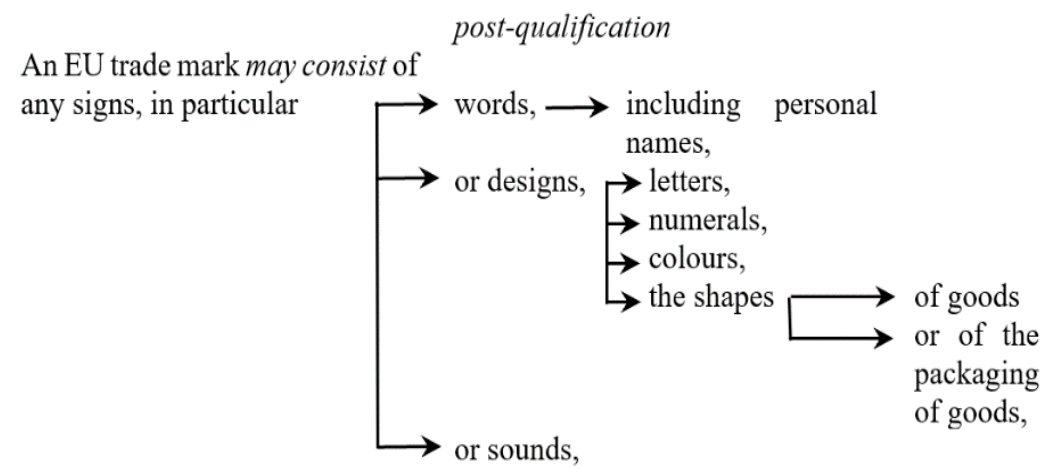

provided that such signs are capable of:

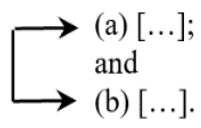

Article 7 'Absolute grounds for refusal' and Article 8 'Relative grounds for refusal' set the limits of the definiendum by means of exclusion which has - as a defining connective - the phrase shall not be registered six times, in complete accordance with the traditional rules of definition as set out by Stebbing (in Robinson 1954: 141), in particular with rule 5 which provides that "The definiens should not be expressed negatively unless the definiendum is negative". The definiendum here is the 'refusal', a list of the characteristics that a sign must not have to be accepted as a trade mark and the method adopted here is intensional.

The other two definitions are relatively shorter than the European one which is made of 1420 words in contrast with 268 words in the WTO agreement and 78 words in the US statute. 
In the WTO agreement the definiendum is positive, but some negative definiens are provided. The structure of this definition is less rigorous, from a cognitive point of view, as extension and intension as methods coexist and from a purely linguistic perspective, shall and may are used as nearly interchangeable items, with may which appear only in the affirmative form and shall in both affirmative and negative.

The US statute definition hinges on two verbs: includes and applies, which is used to introduce the functions - and the characteristics - of a given trademark and thus to provide an intensional definition of the term. The brevity of the definition inserted in Lanham Act is not surprising: as a common law statute, the reasoning procedure is inductive, namely "it imputes a rule from a set of circumstances" (Robertson 2012: 1222) and the decision taken by members of the judiciary may become binding on all subsequent cases pursuant to the principle of precedence. In particular, a considerable number of cases in the section devoted to the statement of the ratio decidendi of the case, "which leads to and justifies the pronouncement of the judgment" (Bhatia 1993: 130) - provide further stipulative intensional definitions of the term trade-mark. The exegetical function (and the prescriptive power) of the Courts has always been apparent: in Duro Pump and Mfg. Co. v. California Cedar Products Co. (1926), in California Packing Corp. v. Tillman Bendel (1930), and in Continental Corp. v. National Union Radio Corp. (1933), the provisions of the Trade-Mark Act of 1905 (15 USCA $\S 85$ ) have been interpreted to determine the legal and linguistic meanings (and implicatures) of the term 'trade-mark' which

[...] is created chiefly by use which must be general, continuous, and exclusive and applied to goods and used in trade under such circumstances of publicity and length of use as to show an intention to adopt the mark for specific goods and to have become known as the distinguishing mark for such goods (Continental Corp. v. National Union Radio Corp., 67 F.2d 938, 942 7th Cir. 1933).

and of the phrase "merchandise of the same descriptive properties" (section 5 and 16 of the Act):

[...] the term "of the same descriptive properties" must be given its ordinary and colloquial meaning, and [...] that the meaning of the phrase "merchandise of the same descriptive properties" must not only be ascertained in the light of the use of the words "goods of the same class," [...] and the words "of [substantially] the same descriptive properties" [...], but must also be construed in connection with the 
predominant phrase of the provision "as to be likely to cause confusion or mistake in the mind of the public or to deceive purchasers," and the predominant word "distinguished" in the first part of the section. (California Packing Corp. v. Tillman Bendel, 40 F.2d 108, 108, 111 C.C.P.A. 1930).

A similar issue related to the choice of the name 'FUCT' for a clothes trademark and to its evocative (and potentially offensive power) is settled in Iancu v. Brunetti (2019) where "The meanings of 'immoral' and 'scandalous' are not mysterious, but resort to some dictionaries still helps to lay bare the problem." Iancu v. Brunetti, 139 S. Ct. 2294, 2299 (2019). Though the dispute concerns the adequacy of the name abovementioned for a trademark, the provisions that regulate the controversy cannot be found in the definitional section 45 of Lanham Act, but in section 2 - Trademarks registrable on principal register; concurrent registration. If in section 45 the definition provided is extensive, as a list of five items - word, name, symbol, or device, or any combination thereof - which is "taken to be literal and [...]explicitly complete in contrast with the default tendency to give three-part lists as symbolically complete" (Jeffries 2010: 70), in section 2 the definition is intensive, as an indented list of items whose standard form is a triple-negative common platform (No... refused... unless) at the beginning followed by the verbal group 'consists of or comprises' followed by a noun phrase which is pre-modified and post-qualified by a qualifying relative clause and a prepositional phrase. The example below, which is taken from section 2, is a graphic representation of the description provided above. The two parts (a) and (b) are examples of extensive definitions which exploit mainly three-part lists, which fulfil a symbolic completeness function. 


\section{Virginia Vecchiato: Definition as a Genre ...}

Graph 2. Graphic representation of syntactic discontinuity in Lanham Act trademark definition.

triple-negative No trademark by which the goods of the applicant common may be distinguished from the goods of others platform: shall be refused registration on the principal register on account of its nature unless it-

\begin{tabular}{|c|c|c|}
\hline $\begin{array}{l}\text { pre- } \\
\text { modification } \\
\text { (three-part list } \\
\text { of adjectives) }\end{array}$ & noun phrase & $\begin{array}{l}\text { post-qualification } \\
\text { (relative clause or } \\
\text { prepositional } \\
\text { phrase) }\end{array}$ \\
\hline
\end{tabular}

(a) Consists

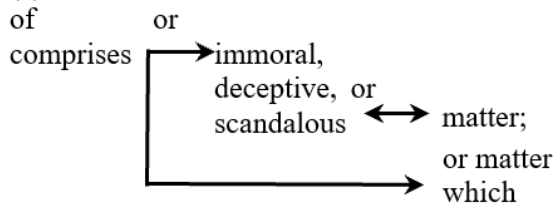

(b) Consists

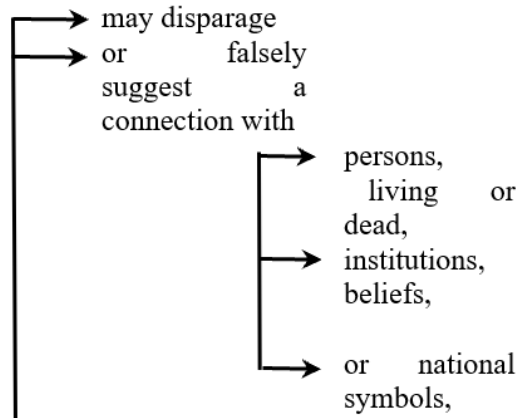

of or

or bring then

into contempt,

or disrepute;

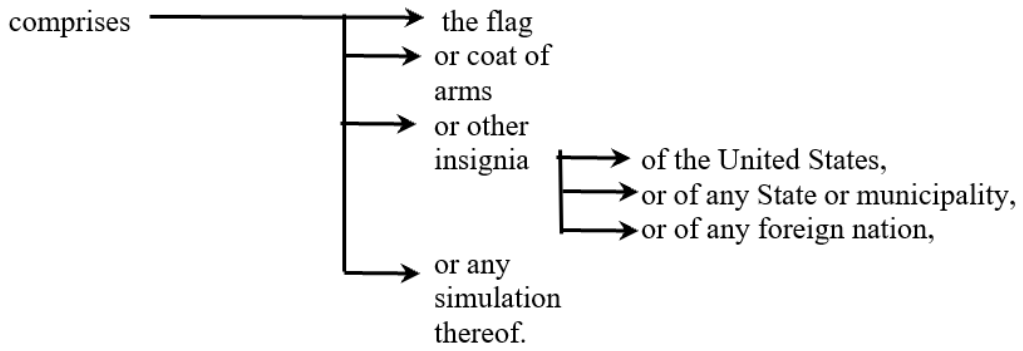


In section 45, and as shown in its graphic representation below, to draw a comparison between the two definitional extracts, the definition is divided into two parts, too, but the former hinges on the verb includes, is extensive and fulfils an explicit completeness function thanks to a five-part list of items whose shape any trademark may assume. The latter hinges on the verb applies, is intensive and fulfils a symbolic completeness function thanks to a three-part list of actions which a trademark allows people to perform in business and commerce - and frequent syntactic discontinuities.

In particular, the scheme below emphasises the double structure of the US act definition (Section 45), where extensive and intensive 'steps' (Hyland 2012; Rasmussen and Engberg 1999) coexist, and confirms legislative provisions as "two-part interactive move-structure consisting of the main 'provisionary clause' and the attendant qualifications" (Bhatia 1993: 130) whose cognitive structure displays a non-linear organization due to the interplay of the main provisionary clause and its qualifications or discontinuities.

Graph 3. Graphic representation of syntactic discontinuity in WTO Agreement trademark.

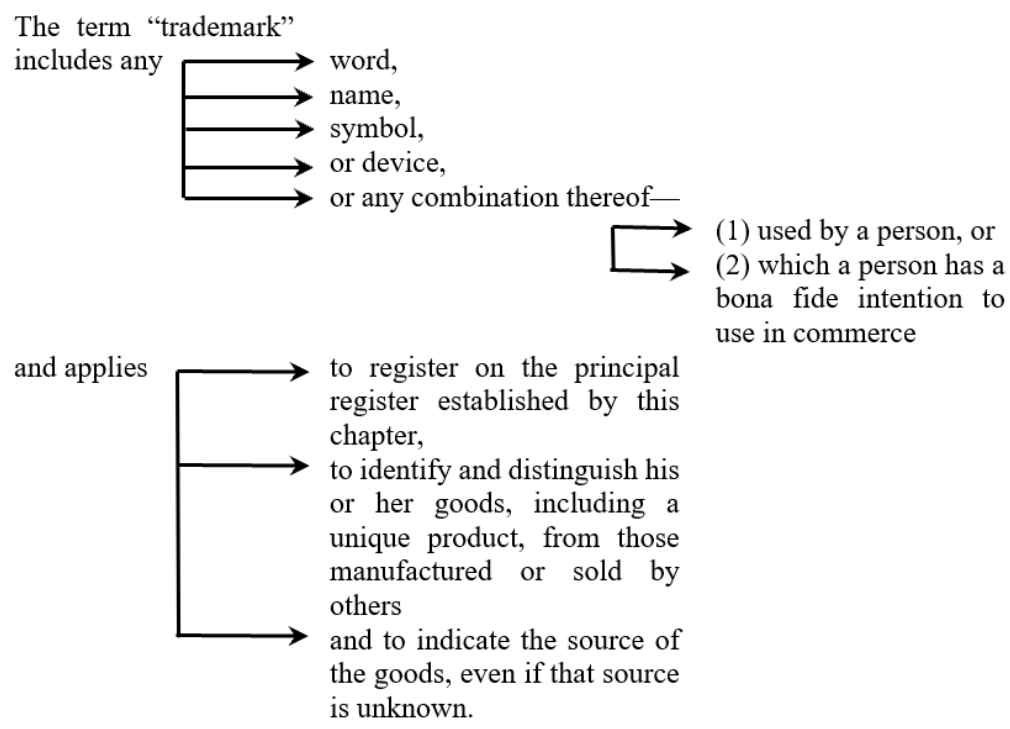


As it frequently happens in EU legal documents too and as demonstrated by Cutts and Wagner (2002), in the US act further definitional information is not provided in the section devoted to definitions (Section 45) but 'somewhere else' (Section 2): as suggested by Cutts and by the principles which underlie the Plain Language Movement, it would be better to "group all the definitions in one place for ease of reference" (Cutts and Wagner 2002: 11). Yet, given this peculiarity, both the US act and the EU legal documents, may be considered as 'diffused stipulative definitions' which develop throughout the whole document by alternating extensive with intensive communicative steps, which symbolically and explicitly express completeness in a partially successful attempt to be all-inclusive and precise.

\section{Conclusion}

From the analysis of the definitions which made up the corpus, the EU definition seems to leave not too much wiggle room to readers and interpretants, or at least seems to cover as many cases as possible, though it is impossible for any legal definition to cover and foresee every possibility that can arise (Robertson 2012). It is possible to say that the trade(-)mark case is neither an example of the use of a common word with an uncommon meaning nor the deliberate use of a word with a flexible meaning: it is an attempt at extreme precision as "[e]xplicit definition is simply a particular application of the law's major approach to precision, i.e., an attempt to put a brand on the mavericks of speech [...] to distinguish the language of the law from common tongue" (Mellinkoff 1963: 23).

Thus the findings of this research confirm the premises, that is common law and civil law linguistic and textual peculiarities merge originally in the EU law, where a code-based written deductive approach - well aware of the constraints afore mentioned - may count on a court-oriented and inductive reasoning where the predictive function of law, despite the abstract context anticipated in legal text written in 'advance', may provide certainty and regularity in civil society. From the analysis carried out on the definitions of 'trademark', stipulative legal definition as a genre results "a staged, goal-oriented, 
social activity" - to paraphrase Martin (1986) definition of genre where different methods of definition corresponds to different, but predictable stages or moves (Bhatia 1993), aimed at establishing how to use - and how to interpret - a given legal term in the context of a legal document and at involving laypeople and experts due to their performative nature. The particularity of common law and the generality of civil law result in a cross-cultural generic variation in the context of the European legal discourse where the definitional section provide terminological explanation and define the domain of application of the term 'trade mark'. As demonstrated above, selected facts lead to the legal drafting (rules) which as a reference has an ideal world. Case law represents the world of reality where relevant facts are taken into account to construe the meaning which is constructed by drafting and which is rarely of universal application (Bhatia 1993).

\section{Bibliography}

Alcáraz, Enrique, and Brian Hughes. 2014. Legal Translation Explained. London: Routledge.

Anselmi, Simona, and Francesca Seracini. 2015. The Transposition of EU Directives into British Legislation. In English Legal Language and Translation, eds. Federica Scarpa and Jan Engberg, 39-62. Roma: Carocci.

Beebe, Barton. 2004. Semiotic Analysis of Trademark Law. UCLA Law Review 51 (3): 621-704.

Bhatia, Vijay K. 1993. Analysing Genre. Language Use in Professional Settings. London: Routledge.

Bhatia, Vijay K. 2010. Legal Writing: Specificity Specification in Legislative Writing: Accessibility, Transparency, Power and Control. In The Routledge Handbook of Forensic Linguistics, eds. Malcom Coulthard and Alison Johnson, 37-51. London: Routledge.

Cacchiani, Silvia. 2015. Performativity and Modal Meanings in the Case Law of the European Court of Justice. In English Legal Language and Translation, eds. Federica Scarpa and Jan Engberg, 125-144. Roma: Carocci. 
Cairns, Huntington. 1936. A Note on Legal Definitions, Columbia Law Review 36 (7): 1099-1106.

Caplan, Harry, trans. 1989. Rhetorica ad Herennium. Harvard: Harvard University Press.

Cutts, Martin, and Emma Wagner. 2002. Clarifying EC Regulations. Whaley Bridge (United Kingdom): Language Commission.

Dacko, Scott. 2008. The Advanced Dictionary of Marketing: Putting Theory to Use. Oxford: Oxford University Press.

Engberg, Jan. 2016. Autonomous EU Concepts: Fact or Fiction? In Language and Culture in EU Law. Multidisciplinary Perspectives, ed. Susan Šarčević, 169-181. London: Routledge. European Union. 2016. Joint Practical Guide of the European Parliament, the Council and the Commission for Persons Involved in the Drafting of European Union Legislation. Available at: https://op.europa.eu/en/publication-detail//publication/3879747d-7a3c-411b-a3a0-55c14e2ba732 (accessed 7 December, 2020).

Felici, Annarita. 2016. Translating EU Legislation from a Lingua Franca: Advantages and Disadvantages. In Language and Culture in EU Law. Multidisciplinary Perspectives, ed. Susan Šarčević, 123-140. London: Routledge.

Fine, Gail J. 1979. Knowledge and Logos in the Theaetetus. The Philosophical Review 88 (3): 366-397.

Fiorito, Lorenzo. 2006. On Performatives in Legal Discourse. Metalogicon 9 (2): 101-112.

Foley, Richard. 2002. Legislative Language in the EU: the Crucible. International Journal for the Semiotics of Law 15: 361-374.

Goźdź-Roszkowski, Stanisław. 2013. Legal Language. In The Encyclopedia of Applied Linguistics, ed. Carol A. Chapelle. Oxford: Wiley-Blackwell, 3281-3289.

Hacker, Peter M.S. 1969. Definition in Jurisprudence. Philosophical Quarterly 19 (77): 343-347.

Harris, Roy, and Christopher Hutton. 2007. Definition in Theory and Practice. London: Bloomsbury.

Hart, Henry. 1954. Definition and Theory in Jurisprudence. Law Quarterly Review 70: 37-60.

Hart, Henry. 1952. Signs and Words. Philosophical Quarterly 2 (6): 5962.

Hurley, Patrick J. 1988. A Concise Introduction to Logic. Belmont: Wadsworth. 
Hyland, Ken. 2012. EAP and Discourse analysis. In Routledge Handbook of Discourse Analysis, eds. Paul Gee and Michael Handford, 412-423. London: Routledge.

Jakobson, Roman. 1959. On Linguistic Aspects of Translation. In On Translation, ed. Reuben A. Brower, 232-239. Cambridge: Harvard University Press.

Jeffries, Lesley. 2010. Critical Stylistics. New York: Palgrave Macmillan.

Jopek-Bosiacka, Anna. 2011. Defining Law Terms: a Cross-Cultural Perspective. Research in Language 9 (1): 9-30.

Kelsen, Hans. 1981. On the Basis of Legal Validity. American Journal of Jurisprudence 26 (1): 178-189.

Kevelson, Roberta. 1992. Property as Rhetoric in Law. Cardozo Studies in Law and Literature 4 (2): 189-206.

Kirkness, Alan. 2004. Lexicography. In The Handbook of Applied Linguistics, eds. Alan Davies and Catherine Elder. 54-81. Oxford: Blackwell.

Locke, John. 1706. An Essay Concerning Human Understanding: In Four Books. Retrieved from http://self.gutenberg.org/ (accessed 3 December 2020).

Mattila, Heikki. 2013. Comparative Legal Linguistics: Language of Law, Latin and Modern Lingua Francas. London: Routledge.

Mellinkoff, David. 1963. The Language of the Law. Eugene: Resource Publications.

Pozzo, Barbara. 2016. Comparative Law and the New Frontiers of Legal Translation. In Language and Culture in EU Law. Multidisciplinary Perspectives, ed. Susan Šarčević, 73-87. London: Routledge.

Putnam, Hilary. 1970. Is Semantics Possible? Metaphilosophy 1 (3): 187-201.

Rasmussen, Kirsten Wølch, and Jan Engberg. 1999. Genre Analysis of Legal Discourse. Hermes, Journal of Linguistics 22: 113-132.

Robertson, Colin. 2010. EU law and Semiotics. International Journal of Semiotics and Law 23: 145-164.

Robertson, Colin. 2011. Multilingual Legislation in the European Union. EU and National Legislative-Language Styles and Terminology. Research in Language 9 (1): 51-67.

Robertson, Colin. 2012. EU Legal English: Common Law, Civil Law, or a New Genre? European Review of Private Law 5-6: 12151240. 
Robertson, Colin. 2016. Multilingual Law. A Framework for Analysis and Understanding. London: Routledge.

Robinson, Richard. 1954. Definition. Oxford: Oxford University Press. Sager, Juan C. 1997. Text Types and Translation. In Text Typology and Translation, ed. Anna Trosborg, 25-41, Amsterdam/Philadelphia: John Benjamins Publishing Company.

Šarčević, Susan. 2016. Language and Culture in EU Law: Introduction and Overview. In Language and Culture in EU Law. Multidisciplinary Perspectives, ed. Susan Šarčević, 1-14. London: Routledge.

Smyrnova, K. 2013. Rethinking EU Soft Law: New Dimensions in Competition Law. Law of Ukraine: Legal Journal 3: 125-132. Swales, John. 1990. Genre Analysis English in Academic and Research Settings. Cambridge: Cambridge University Press.

Swales, John. 2009. Other Floors, Other Voices. London: Routledge.

Werlich, Eric. 1976. A Text Grammar of English. Heidelberg: QuelleMeyer.

White Beck, Lewis. 1956. Kant's Theory of Definition. The Philosophical Review 65 (2): 179-191.

Tiefenbrun, Susan. 1986. Legal Semiotics. Cardozo Arts and Ent. Law Journal 5 (1): 89-156.

Tiersma, Pieter M. 2000. Legal Language. Chicago/London: Chicago University Press. 